\title{
Effects of benthic diatoms, fluff layer, and sediment conditions on critical shear stress in a non-tidal coastal environment
}

\author{
Lars Chresten Lund-Hansen*, Mario Laima ${ }^{\dagger}$, Kim Mouritsen$^{\ddagger}$, Nguyen Ngoc Lam $^{\S}$ \\ and Doan Nhu Hai ${ }^{\S}$ \\ * Marine Ecology, Institute of Biological Sciences, Århus University, Fin landsgade 14, 8200 Århus N, Denmark; \\ ${ }^{\dagger}$ Department of Earth Sciences, Århus University, Ny Munkegade, Build. 520, 8000 Århus, Denmark; ${ }^{\S}$ Institute of Oceanography, \\ 01 Cauda, Nhatrang, Vietnam. *Corresponding author, e-mail: lund-hansen@biology.au.dk
}

\begin{abstract}
Sixteen sediment samples were collected from a square grid $(4 \times 4)$ with a horizontal distance of about $150 \mathrm{~m}$ between positions in Århus Bay in the southwest Kattegat (14 to $15 \mathrm{~m}$ water depth). Critical shear stress $\left(\tau_{\mathrm{c}}\right)$ was measured in all samples and related to sediment parameters: grain-sizes, organic matter, water content, porosity, and chlorophyll- $a(\operatorname{chl} a)$ content, in upper layers. Samples were divided into a low (A) and a high $(\mathrm{B}) \tau_{\mathrm{c}}$ group in relation to an erosion rate. A significant $(P<0.001)$ difference in median $\tau_{\mathrm{c}}$ was found between group A $\left(0.0284 \mathrm{~N} \mathrm{~m}^{-2}\right)$ and $\mathrm{B}\left(0.0380 \mathrm{~N} \mathrm{~m}^{-2}\right)$. Average chl $a$ concentrations in group A $\left(1.4 \mu \mathrm{g} \mathrm{g}^{-1}\right)$ and $\mathrm{B}\left(1.8 \mu \mathrm{g} \mathrm{g}^{-1}\right)$ were not significantly different $(\mathrm{P}=0.47)$ but there was a significant and positive correlation $\left(\mathrm{r}^{2}: 0.7, P<0.001\right)$ between $\tau_{\mathrm{c}}$ and diatom film abundance. Sediment organic matter and water content were significantly higher in group B compared with $\mathrm{A}$, which contradicts that watery and organic rich sediments generally exhibit low $\tau_{\mathrm{c}}$. This was explained by the presence of a diatom film cover on the fluff layer that inhibits the action of erosive forces. A fluff layer is characterized by a high water and organic content. The fluff layer was present in the majority of the samples but the highest average chl $a$ content and a significant $(\mathrm{P}=0.020)$ higher abundance of diatom film was observed in group $\mathrm{B}$ (high $\tau_{\mathrm{c}}$ ). Benthic diatoms were dominated by Haslea crucigeroides, Pleurosigma strigosum, and Bacillaris paxillifer. Spatial variability of sediment parameters was high and variability of a stability/erodibility parameter even exceeded those recorded for highly heterogeneous tidal flats. The occurrence of benthic diatoms at 14-15 m of water depth in the eutrophic Århus Bay was supposedly related to a measured increase in Secci depth in the bay and thereby increased light penetration depth.
\end{abstract}

\section{INTRODUCTION}

Sediment stability influences processes such as sediment transport, deposition, and resuspension in both tidal and non-tidal coastal environments (e.g. Grant et al., 1986; Grant and Gust, 1987; Vos et al., 1988; Paterson, 1989; Underwood \& Paterson, 1993; Yallop et al., 1994; Andersen et al., 2000; Bassoullet et al., 2000). In tidal dominated environments, much research has focused on the role of micro-phytobenthos in relation to sediment stability (e.g. Neumann et al., 1970; de Boer, 1981; Paterson, 1989; Delgado et al., 1991; Madsen et al., 1993; Underwood \& Paterson, 1993; Jonge \& Beusekom, 1995; Austen et al., 1999; Guarini et al., 2000). See also Heinzelmann \& Wallisch (1991), and Paterson (1997) for reviews. These works reported a general positive correlation between critical shear stress for erosion $\left(\tau_{\mathrm{c}}\right)$ and chlorophyll- $a(\operatorname{chl} a)$ content of surface sediments. Light availability for benthic photosynthesis is not a shortcoming on tidal flats, as benthic algae are exposed to light once or twice everyday. On the other hand, the presence of micro-phytobenthos on the sediment surface has been reported to depths of about $200 \mathrm{~m}$ in sub-tropical waters of high down welling irradiance (Cahoon et al., 1990). The present work aims at investigating the relationship between $\tau_{\mathrm{c}}$, micro-phytobenthos biomass/abundance, and sediment parameters such as grain-sizes, organic matter and water content in the coastal eutrophic non-tidal Århus Bay (Denmark). Secci depth in the bay has increased during recent years and a maximum of $16 \mathrm{~m}$ was registered during summer 1998 (Århus County, 2000). Average water depth in the bay is about $14 \mathrm{~m}$ and recent changes in light conditions may support the presence of benthic diatoms at these depths. Major questions addressed in this study are: 1 - Is there a relationship between $\tau_{\mathrm{c}}$ and chl $a$ concentrations in the sediments? 2-If yes, is such relationship similar to the one found in tidal environments? 3 - Is $\tau_{\mathrm{c}}$ related to other sediment parameters as grain-size or organic matter in the sediment? 4Is there a spatial variation of $\tau_{\mathrm{c}}$ and sediment parameters, and how large is the variation?

\section{MATERIALS AND METHODS}

Århus Bay is a semi-enclosed area in the southwest Kattegat, the transitional zone between the low saline (8-10 psu) Baltic Sea and the high saline (30-34 psu) North Sea (Figure 1). Surface water salinities vary between 14 and 29 psu in the bay and bottom water salinities between 20 and 32 psu (Jørgensen, 1996). Low surface and bottom 


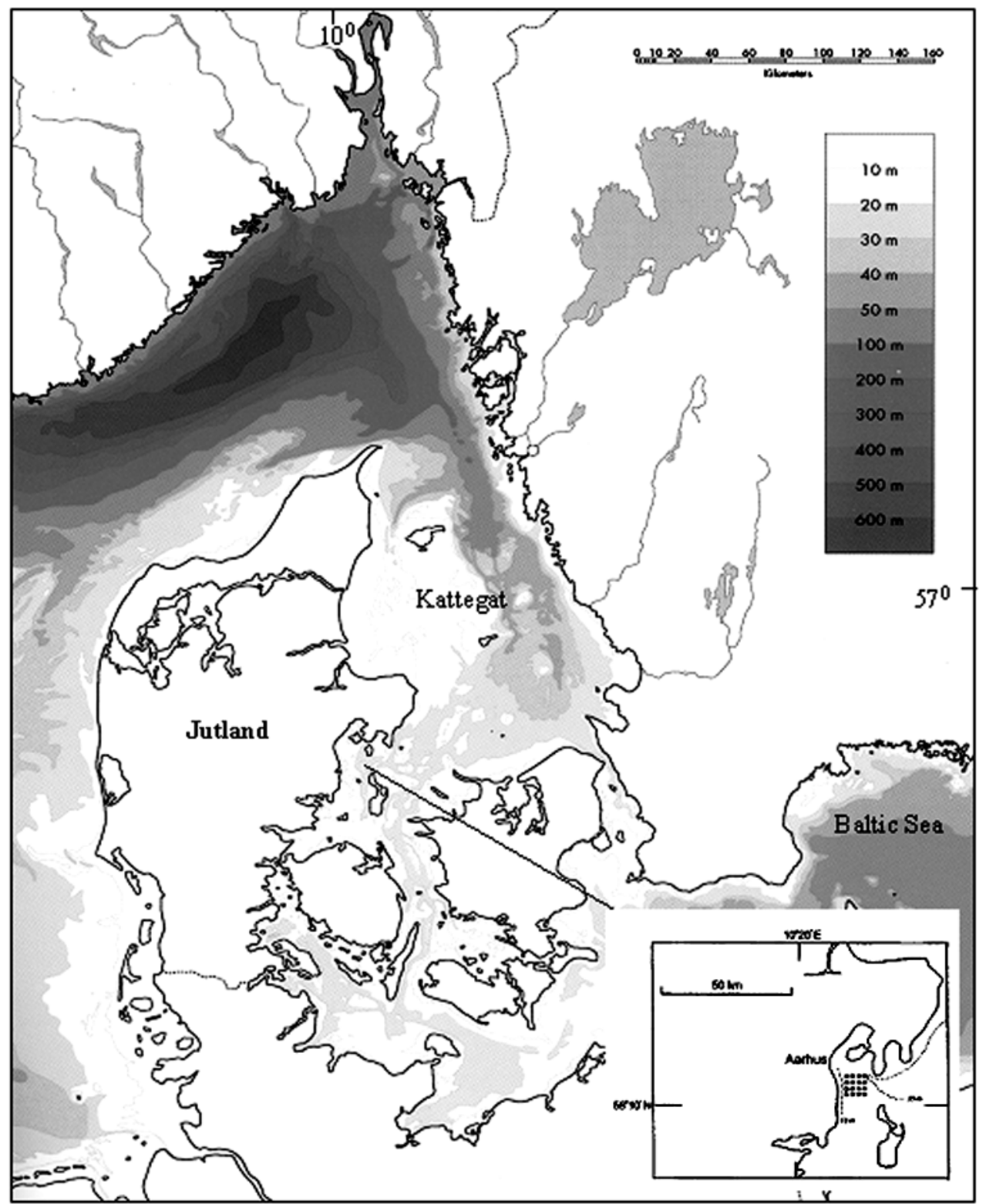

Figure 1. Study area in the south west Kattegat.

water salinities occur during periods of outflow from the Baltic Sea and increased salinities occur in periods of inflow from the Kattegat (Lund-Hansen et al., 1993). Water level variations in the southwest Kattegat are related to wind speeds and directions that by far exceed the tidal range (about $0.4 \mathrm{~m}$ ). Sixteen positions forming a squared grid $(4 \times 4)$ in the western part of the bay were selected for sediment sampling during calm weather conditions in August 1998 (Figure 1). The distance between the positions was about $150 \mathrm{~m}$ (Global Positioning System) and water depths varied between 14 and $15 \mathrm{~m}$ (echo sounder). Sediments were collected using a new hydraulic damped and video equipped box-corer (Lund-Hansen et al., 2001) designed for fluff layer sampling and sediment microtopographic studies (Stolzenbach et al., 1992). Sub-samples are taken once the box-corer is withdrawn and placed on deck. One large (diameter $=85 \mathrm{~mm}$ ) and one minor core (diameter $=50 \mathrm{~mm}$ ) were collected at each position. All cores were brought to the laboratory and placed in a dark thermo-regulated room at $5^{\circ} \mathrm{C}$ where the small cores were immediately processed. The large cores were placed in a stander in a large aerated seawater tank, to keep the sediment in free contact with the circulating water collected during the survey. Before experiments started, sediment cores were kept undisturbed for at least 20 hours to ensure for complete water clearance.

\section{Sediment parameters}

The $85 \mathrm{~mm}$ diameter cores were used for determination of critical shear stress $\left(\tau_{\mathrm{c}}\right)$ after digital imaging (Olympus ${ }^{\circledR}$ C-1400L) of sediment surfaces and depth profiles. The $50 \mathrm{~mm}$ cores were used for determination of diatom species composition, $\operatorname{chl} a$, organic matter and grain size distributions of surface samples $(0-2 \mathrm{~mm})$. Sediments were sieved through a $1.5 \mathrm{~mm}$ sieve to remove gross detritus and macro-fauna. Water content was determined by weight loss at $60^{\circ} \mathrm{C}$ for 48 hours. Organic matter content was determined by loss-on-ignition at $550^{\circ} \mathrm{C}$ for 4 hours. Chl 
$a$ concentrations were measured spectrophotometrically at $664 \mathrm{~nm}$ using the method of Lorenzen (1967) being equivalent to algae biomasses (Underwood \& Paterson, 1993). Diatom species composition was determined by light microscopy. For each of the sixteen samples, species abundance was expressed as: rare, common or dominant. Grain-size distributions were measured by the laser diffraction method (Agrawal et al., 1991) used in the Malvern ${ }^{\circledR}$ Master Sizer-5 after removal of organic matter through $\mathrm{H}_{2} \mathrm{O}_{2}$ treatment.

\section{Laberex experiments}

Sediment $\tau_{\mathrm{c}}$ was determined for each sample using the Laberex chamber, designed to study erosion and sediment stability at low shear stress (Lund-Hansen et al., 1999). The exact relationship between shear stress and impeller motor stirring voltage was determined by laser doppler anemometry in the chamber. It consists of a plexi-glass cylinder with an inner diameter of $85 \mathrm{~mm}$ with a four-bladed impeller located in the centre. Light emitter and receiver are placed outside the chamber and measure light attenuation in the water as a function of increased impeller stirring. Changes in light attenuation are related to changes in absorbency and scattering by particles in suspension and were transformed into a light attenuation coefficient (LAC) $\left(\mathrm{m}^{-1}\right)$ by:

$$
L A C=C-C_{w}=-\left(\ln F / F_{o}\right) / r
$$

where $\mathrm{C}_{\mathrm{w}}$ is the LAC of the water itself regarded as a constant in the experiment, $\mathrm{F}$ the measured and $\mathrm{F}_{\mathrm{o}}$ the initial light intensity (volt), and $\mathrm{r}$ the distance $(\mathrm{m})$ between light emitter and receiver (Wells \& Seok-Yun, 1991). Impeller motor, light emitter and receiver are connected to an A/ D converter operated through the $\mathrm{LABTECH}^{\circledR}$ software for direct monitoring of variables on a computer.

\section{Data analyses}

Statistical analysis was carried out using the Statistical Package for the Social Sciences (SPSS).

\section{RESULTS}

\section{Critical shear stress and sediment parameters}

Results of shear stress measurements are shown in Figure 2 for the samples number 3 (Figure 2a) and 6 (Figure 2b). The $\tau_{\mathrm{c}}$ value is reached where the first and pronounced change in LAC occurs in the time-series (Lund-Hansen et al., 1999). These changes occurred at 2.9 hours (sample 3 ) and at 4.3 hours (sample 6) after start of experiment and relates to $\tau_{\mathrm{c}}$ values of 0.023 and 0.034 $\left(\mathrm{N} \mathrm{m}^{-2}\right)$, respectively. The change in LAC in sample 3 is clearly more gradual compared with sample 6 where LAC exhibits a strong response once $\tau_{\mathrm{c}}$ is reached. The concentration of suspended matter in the Laberex chamber at a LAC of about $1\left(\mathrm{~m}^{-1}\right)$ is about $3 \mathrm{mg} \mathrm{l}^{-1}$ according to an in situ calibration of a transmissometer operating at the same wave length $(630 \mathrm{~nm})$ as the Laberex chamber (LundHansen et al., 2002). A slight increase in LAC is observed during the initial part of the experiments until incipient erosion is reached (Figure $2 \mathrm{~A}-\mathrm{B}$ ). The increase is due to
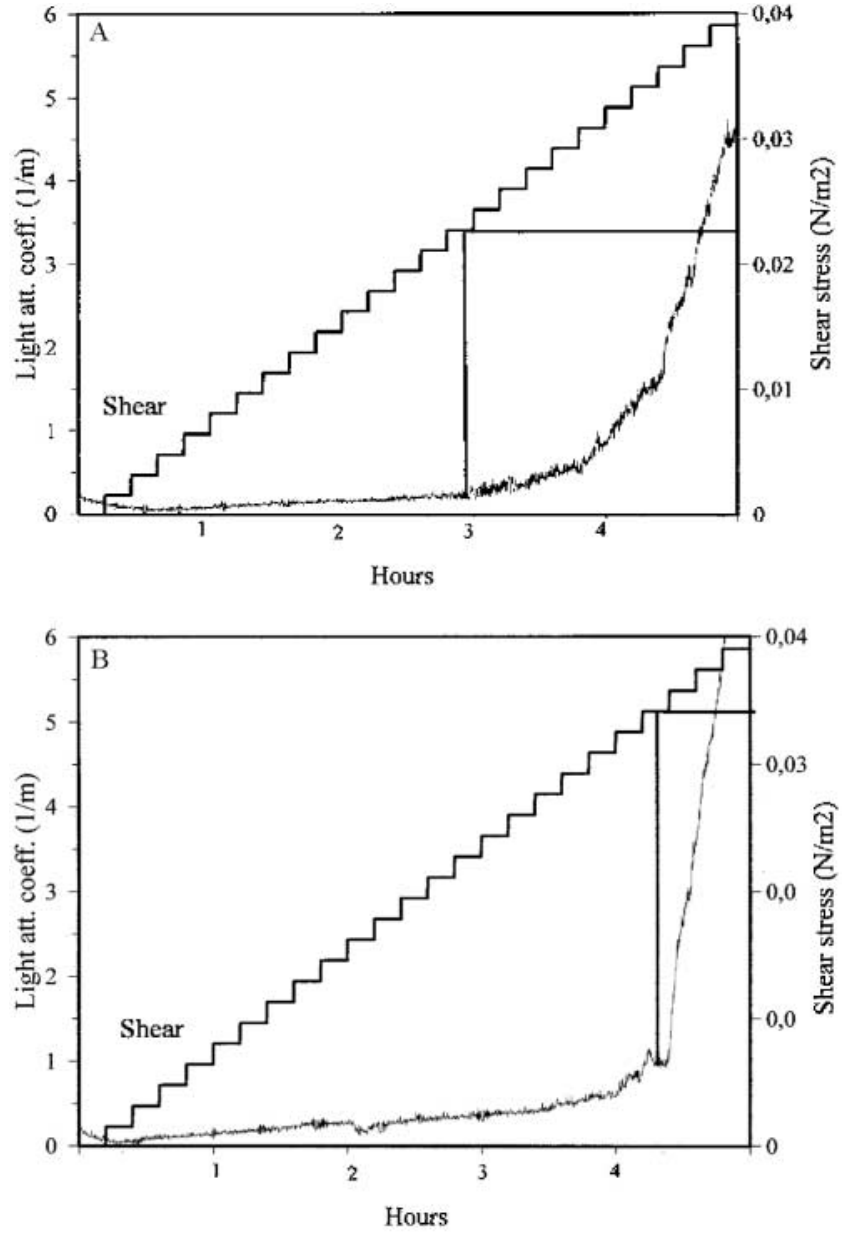

Figure $2 \mathbf{a}-\mathbf{b}$. Shear stress and LAC time-series in sample 3 (2a) and sample $6(2 \mathrm{~b})$.

resuspension of single flocs and aggregates on the sediment surface and whereby LAC increases but this will not affect the determination of $\tau_{\mathrm{c}}$. Erosion rate was determined as a change in LAC relative to a known time interval following the onset of the erosion, which was about 49 times higher in sample $6\left(9.3 \mathrm{~m}^{-1} \mathrm{~h}^{-1}\right)$ compared with sample $3\left(0.19 \mathrm{~m}^{-1} \mathrm{~h}^{-1}\right)$. Samples were accordingly separated into two groups - A and B - based on whether LAC change with time was more gradual or sudden as in samples 3 and 6 , respectively. It turned out that the samples with a gradual LAC change (group A) also exhibited a general low $\tau_{c}$ whereas it was high in group $B$ as shown together with all sediment parameters in Table 1. However, actual $\tau_{\mathrm{c}}$ could not be determined in three samples as the upper limit of $0.04 \mathrm{~N} \mathrm{~m}^{-2}$ in the Laberex chamber was exceeded. These samples were ranked in relation to the remaining 13 samples and placed in the high $\tau_{\mathrm{c}}$ group B. However, a simple comparison of mean values shows that the sand content is higher by $2.2 \%$ whereas the clay content is $3.6 \%$ lower in the low $\tau_{\mathrm{c}}$ group although that these differences are not significant (Table 1). Mean chl a concentration was almost $30 \%$ higher in group B but the difference was not significant $(\mathrm{P}=0.47)$. However, both water content $(\mathrm{P}=0.048)$ and organic matter $(\mathrm{P}=0.011)$ are significant higher in group $\mathrm{B}$ and both the differences in mean $(\mathrm{P}=0.005)$ and median $(P<0.001) \tau_{\mathrm{c}}$ are highly significant. Note that $\mathrm{N}=8$ in group $\mathrm{A}$ and $\mathrm{N}=5$ 
Table 1. Results of sediment analyses with mean $\pm S D$ for each sediment parameter. All cores were separated into group $A$ or $B$ based on $\tau_{c}$ (see text). The P-values are based on Student's t-test which tests for a significant difference in the average between group $A$ and $B$. Numbers in parentheses are not real values as maximum limit in the Laberex chamber was exceeded (see text).

\begin{tabular}{|c|c|c|c|c|c|c|c|c|c|}
\hline $\begin{array}{l}\text { Sample } \\
\text { nr. }\end{array}$ & $\begin{array}{l}\text { Sand } \\
(\%)\end{array}$ & $\begin{array}{l}\text { Silt } \\
(\%)\end{array}$ & $\begin{array}{l}\text { Clay } \\
(\%)\end{array}$ & $\begin{array}{l}\mathrm{H}_{2} \mathrm{O} \\
(\%)\end{array}$ & $\begin{array}{c}\text { Poro. } \\
(\%)\end{array}$ & $\begin{array}{l}\text { Org. } \\
(\%)\end{array}$ & $\begin{array}{c}\text { Chl.a } \\
(\mathrm{myg} / \mathrm{g})\end{array}$ & $\left(\mathrm{N} \mathrm{m}^{-2}\right)$ & $* 100$ \\
\hline \multirow[t]{8}{*}{ A } & 13 & 8.4 & 62.9 & 17.5 & 85 & 1.1 & 12.7 & 1.8 & 1.9 \\
\hline & 3 & 10 & 73.7 & 16.2 & 74 & 0.9 & 10.3 & 1.2 & 2.3 \\
\hline & 4 & 25 & 59.6 & 15.2 & 63 & 0.9 & 6.5 & 0.1 & 2.6 \\
\hline & 9 & 24 & 59.1 & 15.8 & 75 & 0.9 & 10.4 & 1 & 2.78 \\
\hline & 11 & 16 & 63.6 & 28.7 & 74 & 1 & 10.1 & 2.2 & 2.9 \\
\hline & 5 & 34 & 50.3 & 15.5 & 66 & 1 & 6.6 & 3 & 3.25 \\
\hline & 8 & 21 & 61.6 & 17.9 & 69 & 0.9 & 7.3 & 0.4 & 3.25 \\
\hline & 10 & 18 & 62.4 & 17 & 73 & 0.8 & 9.1 & 1.5 & 3.25 \\
\hline Mean \pm SD & & $19.6 \pm 3.0$ & $61.7 \pm 2.3$ & $18.0 \pm 1.6$ & $72.5 \pm 2.3$ & $0.92 \pm 0.03$ & $9.1 \pm 0.8$ & $1.4 \pm 0.3$ & $2.78 \pm 4.95$ \\
\hline \multirow[t]{8}{*}{ B } & 16 & 20 & 62.7 & 19.9 & 79 & 1 & 11.8 & 3.2 & 3.42 \\
\hline & 6 & 14 & 63.7 & 22.2 & 71 & 0.8 & 9.4 & 2 & 3.42 \\
\hline & 14 & 12 & 64.4 & 23.7 & 81 & 0.9 & 12.3 & 2.6 & 3.6 \\
\hline & 15 & 14 & 64.5 & 21.6 & 84 & 0.9 & 12.7 & 1.1 & 3.7 \\
\hline & 2 & 30 & 55.6 & 14.2 & 82 & 1 & 11.7 & 0.5 & 3.9 \\
\hline & 12 & 12 & 60.7 & 27.7 & 75 & 0.9 & 12.5 & 0.8 & $(4.0)$ \\
\hline & 1 & 13 & 60.5 & 26.2 & 77 & 1.1 & 10.4 & 1 & $(4.1)$ \\
\hline & 7 & 24 & 58.7 & 17.3 & 78 & 0.9 & 13.1 & 3 & $(4.2)$ \\
\hline Mean \pm SD & & $17.4 \pm 2.4$ & $61.4 \pm 1.1$ & $21.6 \pm 1.6$ & $78.5 \pm 1.5$ & $0.92 \pm 0.03$ & $11.7 \pm 0.4$ & $1.8 \pm 0.4$ & $3.61 \pm 2.03$ \\
\hline $\mathrm{P}$ & & 0.57 & 0.9 & 0.13 & 0.048 & 0.88 & 0.011 & $0.47^{1}$ & $<0.001 * 1$ \\
\hline
\end{tabular}

${ }^{1}$ Mann-Whitney test and $*$ indicates that this $P$ value was for the difference in the median whereas $P$ for the mean was $0.005-(\mathrm{n}=8$ group $\mathrm{A}, \mathrm{n}=5$ group $\mathrm{B}$ ).

in group B as the three high but unknown $\tau_{\mathrm{c}}$ values were not include in this test.

\section{Fluff layer and diatoms}

Sediment surfaces and down core conditions are shown for samples 12 (Figure $3 \mathrm{~A}-\mathrm{B}$ ) and 4 (Figure $4 \mathrm{~A}-\mathrm{B}$ ). Images were captured in colour but these were discarded for reproduction purposes. However, these samples were chosen, as they exhibit typical features of group A (sample 4) and B (sample 12) rather than being representatives of the two groups. For instance, $\tau_{\mathrm{c}}$ is higher $\left(\tau_{\mathrm{c}}>0.04 \mathrm{~N} \mathrm{~m}^{-2}\right)$ in sample 12 as compared to sample $4\left(\tau_{\mathrm{c}}=0.026 \mathrm{~N} \mathrm{~m}^{-2}\right)$, organic and water content, and chl $a$ are also higher in sample 12 in accordance with general trends (Table 1). A 1-2 mm thick dark grey surface layer is located on top of a lighter grey layer in sample 12 (Figure $3 \mathrm{~A}-\mathrm{B}$ ), and a quite similar surface layer occurred in all group B samples. A less distinct but similar dark grey layer was found in six of the eight group A samples albeit the layer was absent in sample 4. There is a tendency that the boundary between the surface layer and the underlying layer was less well defined in group B compared to A as in sample 12 (Figure 3A). However, organic matter and water content increases towards the sediment surface in both group $\mathrm{A}$ and $\mathrm{B}$ demonstrated by an organic matter increase from $8.4 \%$ at $17-22 \mathrm{~mm}$ depth in the sediment to $12.5 \%$ at the surface $(0-2 \mathrm{~mm})$ as in sample 12. Water content increased similarly from $64.9 \%$ to $75.0 \%$ between $17-22 \mathrm{~mm}$ and 2-7 mm. This emphasizes the presence of an organic and water rich surface layer. In fact, the dark grey surface layer in sample 12 is recognized as a fluff layer, characterized by a loosely compacted, organic and water content rich layer on top of a more consolidated sediment (Stolzenbach et al., 1992). The high organic content of a fluff layer follows that such layer consists of recently deposited material, which is then degraded through biogeochemical processes and incorporated into the sediment over time. The fluff accumulates on the sediment surface during calm weather periods from where it is frequently resuspended in shallow water regions (Lund-Hansen et al., 1999; Edelvang et al., 2002) as fluff layer critical shear stress is generally low (Stolzenbach et al., 1992). However, both median $\tau_{\mathrm{c}}$, organic and water content are significantly higher in group B (high $\tau_{\mathrm{c}}$ ) compared with A (Table 1) which opposes the above characteristics of a fluff layer. Now, a major part of the surface in sample 12 is covered by benthic diatoms (Figure 3B) shown by the darker grey colours at the periphery of the core as well as in the central part (Figure 3B). The sample 4 sediment surface was not covered by benthic diatoms but these were present in varying degrees in seven of the eight group A samples. The dark grey colours at the rim in the northwest and southeast part of the sample 4 sediment surface are due to shadow effects (Figure 4B). On the other hand, the data set showed no correlation between $\tau_{c}$ and chl $a$ concentrations as observed in other studies (see Introduction). The absence of such correlation might, however, be related to the fact that chl $a$ analyses were performed on samples from the small cores and not on the cores that were used for determination of $\tau_{\mathrm{c}}$ as this would have destroyed the samples. Instead, a visual inspection of digital images and three separate rankings of the samples were carried out in order to detect any relations between: 1) $\tau_{\mathrm{c}}$, 2) diatom film abundance, 3) polychaet abundance, and 4) surface topographic homogeneity. There is well known positive relation between $\tau_{\mathrm{c}}$ and diatom 
A

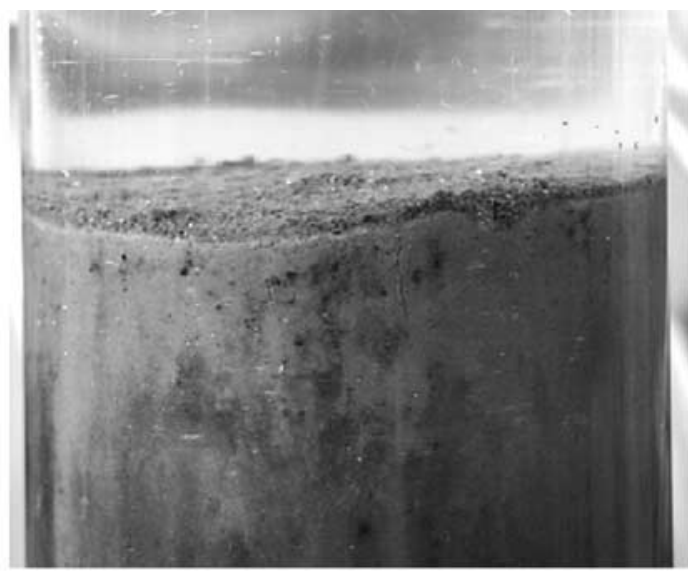

B

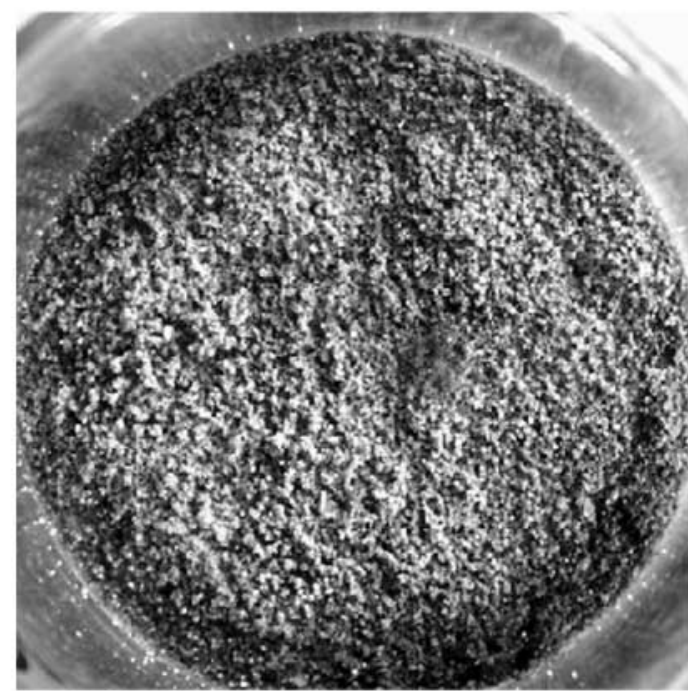

Figure 3a-b. Sample 12: Photographs of profile (3a) and surface $(3 \mathrm{~b})$. Colours were discarded for reproduction purposes.

film abundance expressed as chl $a$ (see Introduction). Bioturbation and sediment ingestion by polychaetes has been shown to reduce critical shear stress (Aller \& Yingst, 1985), and polychaete burrows are observed in sample 4 (Figure 4A) but not in 12 (Figure 3A). Surface roughness, here expressed as topographic homogeneity, also affects critical shear stress as a smooth sediment surface, in general, raises critical shear stress (McCave, 1984). For instance, the sample 12 sediment surface is topographically more homogeneous and smooth with less borrows and hollows as in sample 4 (Figure $3 \mathrm{~B}-4 \mathrm{~B}$ ). The sediment surface in sample 4 is the less homogeneous in group $\mathrm{A}$ where the surface of the other samples more resemble sample 12. Now, each of the surface and depth profile images were assigned a score value between 1 (low) and 16 (high) in relation to diatom film abundance, i.e. how much of the sediment surface was covered by benthic diatoms, polychaete abundance at the rim, and surface topographic homogeneity. Median $\tau_{\mathrm{c}}$ was calculated for the low $(1-8)$ and high (9-16) score groups as this parameter showed a significant difference between group $\mathrm{A}$ and B (Table 1). A two-tailed Mann-Whitney test was applied to test for differences between the two groups. Results show that surface topographic homogeneity seemed to be associated with a high median $\tau_{\mathrm{c}}$ value but the relation appeared only marginally significant $(\mathrm{P}=0.058)$.
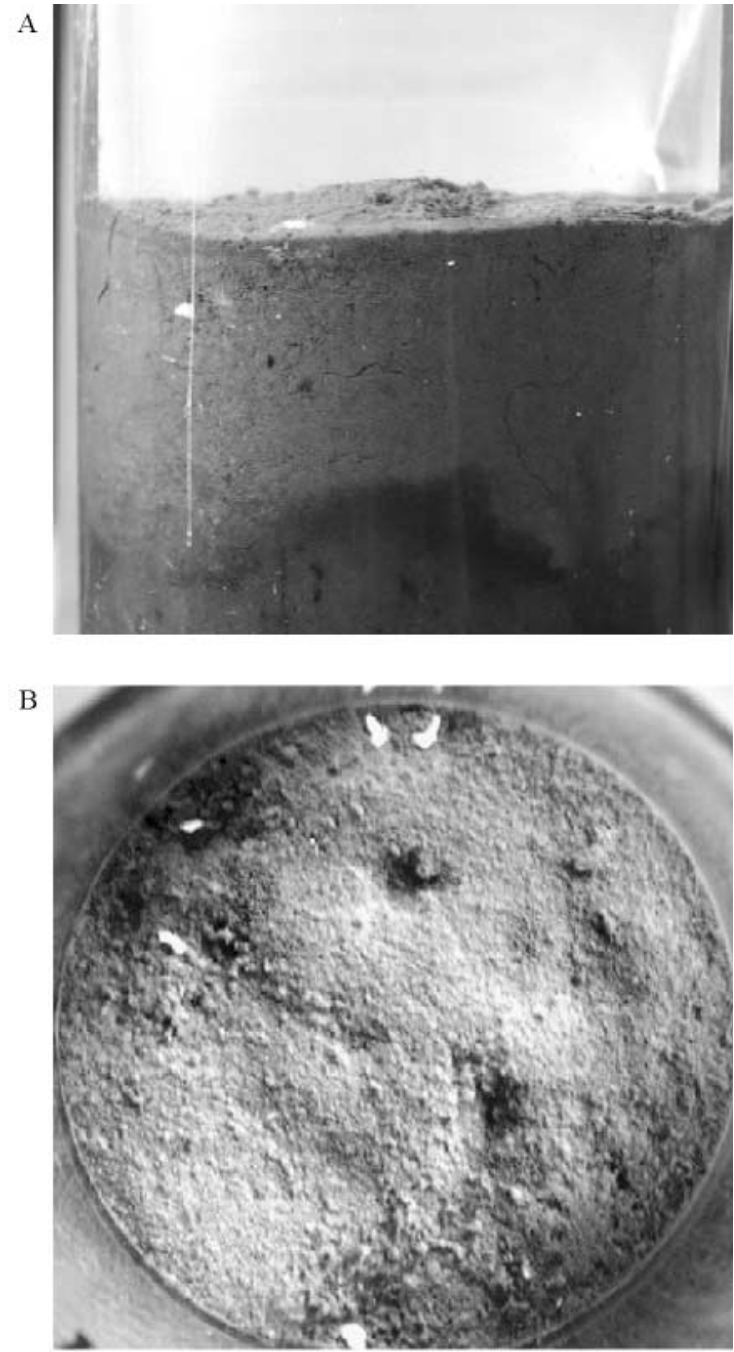

Figure 4a-b. Sample 4: Photographs of profile (4a) and surface $(4 \mathrm{~b})$. Colours were discarded for reproduction purposes.

Diatom film abundance was significantly $(\mathrm{P}=0.02)$ related to median $\tau_{\mathrm{c}}$ which was not the case regarding polychaete abundance $(\mathrm{P}=0.126)$. However, organic matter and water content were positively related to $\tau_{\mathrm{c}}$ likely explaining principal part of the variance in $\tau_{\mathrm{c}}$ (Table 1). A partial correlation analysis was hence carried through correlating $\tau_{\mathrm{c}}$ with surface topographic homogeneity, organic matter and water content, each time controlling for the effects of diatom abundance. Results show that none of these three parameters alone influences significantly the $\tau_{\mathrm{c}}$ value. Furthermore, the correlation between $\tau_{\mathrm{c}}$ and diatom abundance, controlling for topographic homogeneity, water, and organic mater content, showed that diatom abundance was the most important parameter explaining the largest variability of $\tau_{\mathrm{c}}\left(\mathrm{r}^{2}: 0.70, P<0.001\right)$ (Table 2$)$. These results strongly suggest that topographic homogeneity, water, and organic matter content are related to the presence of diatoms rather than being determinants of $\tau_{\mathrm{c}}$. Results show that the homogenous surface was covered by a diatom film which exhibited a high $\tau_{\mathrm{c}}$ and that organic and water content were high in the diatom covered surface fluff layer (Table 2). It was observed during the Laberex experiments that the sediment surface broke apart in flakes $(0.5-1 \mathrm{~cm})$ and were brought into suspension once $\tau_{c}$ was reached in the major part of the group B samples. This phenomenon attributes 
Table 2. Correlation matrix showing the association between critical shear stress and potentially related parameters. $r^{2}$ and $p$ values (bold) are given. $\mathrm{P}$-values are one-tailed probabilities regarding shear stress and two-tailed otherwise. $D f=14$ for all tests.

\begin{tabular}{lclll}
\hline & $\begin{array}{l}\text { Diatom } \\
\text { film }\end{array}$ & $\begin{array}{l}\text { Surface } \\
\text { homogeneity }\end{array}$ & $\begin{array}{l}\text { Organic } \\
\text { material }\end{array}$ & $\begin{array}{l}\text { Water } \\
\text { content }\end{array}$ \\
\hline Shear stress & 0.70 & 0.20 & 0.12 & 0.17 \\
& $<\mathbf{0 . 0 0 1}$ & $\mathbf{0 . 0 4 2}$ & $\mathbf{0 . 1 0}$ & $\mathbf{0 . 0 5 8}$ \\
Diatom film & & 0.33 & 0.30 & 0.28 \\
& & $\mathbf{0 . 0 2 1}$ & $\mathbf{0 . 0 2 8}$ & $\mathbf{0 . 0 3 4}$ \\
Surface & & & 0.02 & 0.015 \\
homogeneity & & & $\mathbf{0 . 6 0}$ & $\mathbf{0 . 6 5}$ \\
Organic & & & & 0.81 \\
material & & & & $<\mathbf{0 . 0 0 1}$ \\
\hline
\end{tabular}

to the presence of the diatoms as flocs and aggregates are still kept together by diatom film. This is in agreement with other studies, which showed a correlation between the brake up in flakes and the presence of diatom films (Madsen et al., 1993; Laima et al., 1998). About 30 species of benthic diatoms were identified but three species of epipelic benthic diatoms dominated all 16 samples: Haslea crucigeroides, Pleurosigma strigosum, and Bacillaria paxillifer. There were no clear differences between group A and B in relation to the occurrence of both dominant and less dominant species, and there were no clear differences in species composition or abundances between positions. A few pelagic algae species were found in all samples.

\section{DISCUSSION \\ Critical shear stress}

The in vitro measured $\tau_{\mathrm{c}}$ values lie within the range reported for in situ studies in areas with similar sedimentological conditions as Århus Bay. For example, erosional studies at a water depth of $16 \mathrm{~m}$ in Buzzards Bay showed an average $\tau_{\mathrm{c}}$ of $0.023 \mathrm{~N} \mathrm{~m}^{-2}(\mathrm{~N}=9)$ (Young \& Southard, 1978). This value lies within the range of the median $\tau_{\mathrm{c}}$ $\left(0.0278 \mathrm{~N} \mathrm{~m}^{-2}\right)$ measured for group A sediments (Table 1$)$. Other authors reported a $\tau_{\mathrm{c}}$ of about $0.05 \mathrm{~N} \mathrm{~m}^{-2}$ obtained at in situ in water depths from 5 to $6 \mathrm{~m}$ (Maa et al., 1998). However, average current shear stress in Århus Bay, measured during a 1.3 year long period at a position close $(\sim 2 \mathrm{~km})$ to the present sampling positions, is about $0.01 \mathrm{~N} \mathrm{~m}^{-2}$ but may reach $0.1 \mathrm{~N} \mathrm{~m}^{-2}$ in periods of wind wave generated shear stress (Lund-Hansen et al., 1997). Shear stresses of 0.01 and $0.1 \mathrm{~N} \mathrm{~m}^{-2}$ relates to current speeds of about $10 \mathrm{~cm} \mathrm{~s}^{-1}$ and $30 \mathrm{~cm} \mathrm{~s}^{-1}$ at $1.0 \mathrm{~m}$ above the seabed, respectively, depending on drag coefficient $\left(\mathrm{C}_{\mathrm{d}}\right)$ and water density $\left(\rho_{\mathrm{w}}\right)$ as: $\tau=\mathrm{C}_{\mathrm{d}} \rho_{\mathrm{w}} \mathrm{u}^{2}$ (Soulsby, 1997). In comparison to minimum measured $\tau_{\mathrm{c}}$ of $0.019 \mathrm{~N} \mathrm{~m}^{-2}$ (Table 1), these results show that erosion only occurs very infrequently at the sampling positions. On the other hand, it must be anticipated that the sediment surface is only covered by diatoms during spring, summer and part of the autumn where light intensity is high enough but whereby the observed entrapment of the fluff layer by the benthic diatoms only acts on a yearly scale.

\section{Fluff layer}

Studies of fluff layer critical shear stress along a river mouth-depositional area gradient at different water depths $(16-47 \mathrm{~m})$ showed an average of $0.018 \mathrm{~N} \mathrm{~m}^{-2}(\mathrm{~N}=8)$ with a range between 0.021 and $0.013 \mathrm{~N} \mathrm{~m}^{-2}$ (Jähmlich et al., 2002). This average is comparable to the minimum $\tau_{c}$ of $0.019 \mathrm{~N} \mathrm{~m}^{-2}$ of group $\mathrm{A}$ whereas the averages reached 0.0278 and $0.0361 \mathrm{~N} \mathrm{~m}^{-2}$ in groups $\mathrm{A}$ and $\mathrm{B}$, respectively (Table 1). Apart from any differences in floc and aggregate sizes between the Jähmlich et al. (2002) study and the present, these results clearly show that the presence of benthic diatoms strongly increases critical shear stress and even in samples with a low diatom film score value as in group A (Table 1). This detailed comparison is justified as the hydraulic damped box-corer and the Laberex chamber were used in both studies. The development, maintenance, and general dynamics of fluff layers are less studied although it is known that fine-grained organic rich material enriched in clay minerals (fluff layer/material) is responsible for the transportation of particulate bound pollutants, for instance heavy metals (Sadiq, 1992). It has recently been shown that the fluff layer acted as conveyer belt in the transportation of organic pollutants on a riverdepositional area gradient in the southern Baltic Sea (Witt et al., 2001). Heavy metal concentrations were not measured in the present study but that the benthic diatoms strongly raise the critical shear stress of the fluff layer has some implications. For instance, the transport of associated heavy metals and other particle bound pollutants will remain deposited for a longer period in the shallow water region where down welling irradiance is high enough to sustain populations of benthic diatoms. This is especially the case in the non-tidal Århus Bay where $\tau_{\mathrm{c}}$ only infrequently is higher than $0.01 \mathrm{~N} \mathrm{~m}^{-2}$, although that the earlier supposed yearly variation in benthic diatom abundance has to be considered.

\section{Chlorophyll-a}

Recent studies in tidal environments have shown a positive correlation between $\tau_{\mathrm{c}}$ and chl $a$ concentration (Vos et al., 1988; Delgado et al., 1991; Paterson, 1989; Heinzelmann and Wallisch, 1991; Yallop et al., 1994). A similar relation was also found in the present study shown by the significant correlation $\left(\mathrm{r}^{2}: 0.7, P<0.001\right)$ between shear stress and abundance of diatom film (Table 2). The correlation was, however, based on quantative image analyses rather than direct measurement of chl $a$ in the sediment which showed no correlation (Table 1). Chl $a$ analyses were carried out on samples collected from the small cores and not from the cores that were actually used for $\tau_{\mathrm{c}}$ the determination as such sampling would have disturbed the samples. Average sediment surface chl $a$ concentrations in Århus Bay are $1.6 \mu \mathrm{g} \mathrm{g}^{-1}$ (Table 1), or two times higher as those measured in a tropical embayment between 20 and 60 meter of water depths (Burford et al., 1994). And also higher compared with the mean of $0.6 \mu \mathrm{g} \mathrm{g}^{-1}$ on the subtropical $\left(34^{\circ} \mathrm{N}\right)$ south-east coast of the US at water depths between 10 and $19 \mathrm{~m}$ (Cahoon et al., 1990). Chl $a$ concentrations in Århus Bay are low compared with the Danish Wadden Sea area where concentrations of about $20 \mu \mathrm{g} \mathrm{g}^{-1}$ were reported for intertidal sand flats 
(Mouritsen et al., 1998) and $219.1 \mu \mathrm{g} \mathrm{g}^{-1}$ in mudflats (Austen et al., 1999). The diatom Bacillaria paxillifer was assigned a low stability coefficient in a study comparing the effects of different diatom species on sediment stability (Holland et al., 1974). Bacillaria paxillifer was one of the three dominant species in Århus Bay. However, the low stability coefficient is difficult to evaluate in the present study as Holland et al. (1974) compared Bacillaria paxillifer to species that were not found in the Århus Bay.

\section{Sediment parameters and variability}

Organic matter and water contents were both significantly higher in group B (high $\tau_{\mathrm{c}}$ ) whereas there were no significant differences in grain-sizes between the two groups (Table 1). The statistical analyses comprised only three main groups of grain-sizes: sand, silt and clay, which is, however, a very coarse scale regarding grainsize distributions. Nevertheless, the sediment samples are typical cohesive sediments shown by the high proportions of silt and clay $(60-70 \%)$, high organic matter $(\sim 10 \%)$, and water $(\sim 75 \%)$ contents (Table 1$)$. The physical characteristics of the cohesive sediments, in relation to an applied shear stress, are then generally governed by variations in organic matter and water contents, compared to the small variations in grain-sizes (McCave, 1984). However, the present study shows that benthic diatoms occur at relatively deep water $(14-15 \mathrm{~m})$ even in an eutrophic bay where down welling irradiance is generally controlled by phytoplankton and dissolved organic matter (Jørgensen, 1996). However, no obvious patterns regarding any of the sediment parameters were recognized in Århus Bay, i.e. high $\tau_{\mathrm{c}}$ values or samples with a high organic content were clustered in a separate part of the grid, for instance. The variability of $\tau_{\mathrm{c}}$ in Århus Bay is high with a coefficient of variation $(\mathrm{CV})$ of $18.6 \%$ which is a high value compared the $\mathrm{CV}$ of $12.8 \%$ reported for areas recognized as highly heterogeneous, for instance along an intertidal gradient. Paterson et al. (1990) carried out replicate measurements of critical pulse velocity $\left(\mathrm{CPV}, \mathrm{m} \mathrm{s}^{-1}\right)$ on a range of stations covering several different tidal flats (9 to $25 \mathrm{~km}$ apart) and different tidal levels (high, medium, and low). Concentrating on two hours of exposure, a CPV value (chosen at random among the mean, mean $+\mathrm{SD}$, and mean - SD) was deduced directly from graphs shown by Paterson et al. (1990). In this way, 13 CPV readings were obtained, embracing 5 different tidal flats and 2-3 different tidal levels, and the calculated $\mathrm{CV}$ was $12.8 \%$. It was expected that the exposure of heterogeneous tidal flats to strong current and wave shear stress variations would result in a higher CV compared with the seemingly homogeneous sampling positions in Århus Bay. High spatial variability in benthic diatom patchiness in a tidal flat has also been recognized by Jonge and Beusekom (1995) and Delgado et al. (1991) noted a clear spatial variation in that concentrations of benthic diatom were increased at less exposed stations to waves and currents.

\section{Benthic diatoms in Arhus Bay}

The Secci depth has increased from $6 \mathrm{~m}$ in 1987 to about $8.5 \mathrm{~m}$ in 1998 at a central position in the bay as shown by weekly measurements, and a maximum Secci depth of
16 m was reached in July 1998 (Århus County, 2000). It is unlikely that benthic diatoms in any way have been transported from shallow water as June, July, and August 1998 were governed by calm wind conditions. The increased Secci depth and thus increased light penetration depth observed in 1998 was most likely the background for development of benthic diatom films at these water depths. The increased light penetration depth might be related to the reduction in nutrient loads into the Ârhus Bay and surrounding waters that has been observed in recent years, especially regarding phosphorus (Århus County, 2000).

This study was a part of the BIOTA and the Skallingen Research Projects, financially supported by the Danish Research Council for Natural Sciences contract numbers: SNF9901789, SNF9701836, and SNF21-01-0513.

\section{REFERENCES}

Andersen, T.J., Mikkelsen, O.A., Møller, A.L. \& Pejrup, M., 2000. Deposition and mixing depths on some European intertidal mudflats based on ${ }^{210} \mathrm{~Pb}$ and ${ }^{37} \mathrm{Cs}$ activities. Continental Shelf Research, 20, Special Issue 12-13, 1569-1591.

Aller, R.C. \& Yingst, J.Y., 1985. Effects of the marine depositfeeders Heteromastus filiformis (Polychaeta), Macoma balthica (Bivalvia), and Tellina texana (Bivalvia) on averaged sedimentary solute transport, reactions rates, and microbial distributions. Fournal of Marine Research, 43, 615-645.

Austen, I., Andersen, T.J. \& Edelvang, K., 1999. The influenc of benthic diatoms and invertebrates on the erodibility of an intertidal mudflat, the Danish Wadden Sea. Estuarine, Coastal, and Shelf Science, 49, 99-111.

Agrawal, Y.C., McCave, I.N. \& Riley, J.B., 1991. Laser diffraction size analysis. In: Principles, methods, and application of particle size analysis, 119-128. Syvitski, J.P.M. (Ed.) Cambridge University Press.

Bassoullet, Ph., Hir, Le. P., Gouleau, D. \& Robert, S., 2000. Sediment transport over an intertidal mudflat: Field investigations and estimation of fluxes within the "Baie de MarennesOléron" (France). Continental Shelf Research, 20, Special Issue 12-13, 1635-1653.

Burford, M.A., Long, B.G \& Rothlisberg, P.C., 1994. Sedimentary pigments and organic carbon in relation to microalgal and benthic faunal abundance in the Gulf of Carpentaria. Marine Ecology Progress Series, 103, 111-117.

Cahoon, L.B., Redman, R.S. \& Tronzo, C.R., 1990. Benthic microalgal biomass in sediments of Onslow Bay, North Carolina. Estuarine, Coastal and Shelf Science, 31, 805-816.

de Boer, P.L., 1981. Mechanical effects of micro-organisms on intertidal bedform migrations. Sedimentology, 28, 129-132.

Delgado, M., Jonge, V.N. \& Peletier, H., 1991. Experiments on resuspension of natural microphytobenthos populations. Marine Biology, 108, 321-328.

Edelvang, K., Lund-Hansen, L.C., Christiansen, C., Petersen, O.S., Uhrenholdt, T., Laima, L. \& Berastegui, D.G., 2002. Modelling of suspended matter transport from the Oder river. Journal of Coastal Research, 18, 62-74.

Grant, J., Bathmann, U.V. \& Mills, E.L., 1986. The interaction between benthic diatom films and sediment transport. Estuarine, Coastal and Shelf Science, 23, 225-238.

Grant, J. \& Gust, G., 1987. Prediction of coastal sediment stability from photopigment content of mats of purple sulphur bacteria. Nature, 330, 244-246.

Guarine, J.-M., Blanchard, G. \& Gros, P., 2000. Quantification of the microphytobenthic primary production in European 
intertidal mudflats - a modelling approach. Continental Shelf Research, 20, Special Issue 12-13, 1771-1788.

Heinzelmann, C. \& Wallisch, S., 1991. Benthic settlemet and bed erosion. Fournal of Hydraulic Research, 29, 355-371.

Holland, A.F., Zingmark, R.G. \& Dean, J.M., 1974. Quantitative evidence concerning the stabilization of sediment by marine benthic diatoms. Marine Biology, 27, 191-196.

Jähmlich, S., Lund-Hansen, L.C. \& Leipe, T., 2002. Enhanced settling velocities and vertical transport of organic carbon (POC) by aggregation of particulate matter in the benthic boundary layer (BBL). Danish fournal of Geography, (Submitted).

Jonge, V.N. \& Beusekom, J.E.E., 1995. Wind- and tide-influenced resuspension of sediment and microphytobenthos from tidal flats in the Ems estuary. Limnology and Oceanography, 40, 766-778.

Jørgensen, B.B. (1996). Case study-Århus Bay. In: Eutrophication in coastal and marine ecosystems, 137-154. Jørgensen, B.B. \& Richardson, K. (Eds.). Coastal and Estuarine Studies, 52. American Geophysical Union.

Laima, M.J.C., Matthiesen, H., Lund-Hansen, L.C. \& Christiansen, G., 1998. Resuspension studies in cylindrical microcosms: Effects of stirring velocity on the dynamics of redox sensitive elements in a coastal sediment. Biogeochemistry, 43, 293-309.

Lorenzen, C.J., 1967. Determination of chlorophyll and pheopigments: spectrophotometric equations. Limnology and Oceanography, 31, 779-787.

Lund-Hansen, L.C., Pejrup, M., Valeur, J. \& A. Jensen, 1993. Gross sedimentation rates in the North Sea-Baltic Sea: Effects of stratification, wind energy transfer, and resuspension. Oceanologica Acta, 16, 205-212.

Lund-Hansen, L.G., Valeur, J, M., Pejrup, M. \& A. Jensen, 1997. Sediment fluxes, resuspension and accumulation rates at two wind-exposed coastal cites and in a sheltered bay. Estuarine, Coastal and Shelf Science, 44, 521-531.

Lund-Hansen, L.C., Christiansen, C., Jensen, O. \& Laima, M., 1999. The LABEREX chamber for studying the critical sherar stress for fine-grained sediment. Danish fournal of Geography, 99, $1-7$.

Lund-Hansen, L.C., Christiansen, G. \& Laima, M., 2001. A new video controlled, hydraulic damped box-corer for sediment/ water interaction studies. Marine Georesources and Geotechnology. 19, 45-51.

Lund-Hansen, L.C., Christiansen, C. \& Eriksen, A.T., 2002. Time-series of suspended particulate matter concentrations in relation to sediment fluxes and particulate settling velocities in a wind-exposed shallow-water coastal embayment. Danish fournal of Geography, (Submitted).

Maa, J.P.-Y, Sanford, L. \& Halka, J.P., 1998. Sediment resuspension characteristics in Baltimore Harbor, Maryland. Marine Geology, 146, 137-145.

Madsen, K.N, Nilsson, P. \& Sundbäck, K., 1993. The influence of benthic microalgae on the stability of a subtidal sediment. Fournal of Experimental Marine Biology and Ecology, 170, 159-177.

McCave, I.N., 1984. Erosion, transport and deposition of finegrained sediments. Geological Society, London, 15, 1050-1067.

Mouritsen, K.M., Mouritsen, L.T. \& Jensen, K.T. 1998. Change of topography and sediment characteristics on an intertidal mud-flat following mass mortality of the amphipod Corophium volutator. Fournal of the Marine Biological Association of the United Kingdom, 78, 1167-1180.

Neumann, A.C., Gebelein, C.D. \& Scoffin, T.P. 1970. The composition, structure and erodibility of subtidal mats, Abaco, Bahamas. Fournal of Sedimentary Petrology, 40, 274-297.

Paterson, D.M., 1989. Short-term changes in the erodibility of intertidal cohesive sediments related to the migratory behavior of epipelic diatoms. Limnology and Oceanography, 34, 223-234.

Paterson, D.M., Crawford, R.M. \& Little, C., 1990. Subaerial exposure and changes in the stability of intertidal and estuarine sediments. Estuarine, Coastal and Shelf Science, 30, 557-567.

Paterson, D.M., 1997. Biological mediation of sediment erodibility: ecology and physical dynamics. In: Cohesive sediments, 215-229. Burt, N., Parker, R. \& Watts. J. (Eds.). Wiley, Chichester.

Sadiq, M., 1992. Toxic metal chemistry in marine environments. Marcel Dekker, Inc. New York. 390 pp.

Soulsby, R., 1997. Dynamics of marine sands. Wallingford. 221 pp.

Stolzenbach, K.D., Newman, K.A. \& Wong, C.S., 1992. Aggregation of fine particles at the sediment-water interface. Fournal of Geophysical Research, 97, 17889-17898.

Underwood, G.J.G.\& Paterson, D.M., 1993. Recovery of intertidal benthic diatoms after biocide treatment and associated sediment dynamics. Fournal of the Marine Biological Association United Kingdom, 73, 25-45.

Underwood, G.C.J. \& Paterson, D.M., 1993. Seasonal changes in diatom biomass, sediment stability and biogenic stabilization in the Severn Estuary. Fournal of the Marine Biological Association United Kingdom, 73, 871-887.

Vos, P.C., de Boer, P.L. \& Misdorp, R., 1988. Sediment stabilization by benthic diatoms in intertidal sandy shoals; Qualitative anbd quantitative observations. In: Tide-influenced sedimentary environments and facies, 511-625. Boer, P.L., Gelder, A. and Nio, S.D. (Eds.).

Wells, J. T. \& K. S.-Yun. 1991. The relationship between beam transmisson and concentrations of suspended particulate matter in the Neuse River Estuary, North Carolina. Estuaries, 14, 395-403.

Witt, G., Leipe, T. \& Emeis, K.-C. 2001. Using fluff layer material to study the fate of particle-bound organic pollutants in the southern Baltic Sea. Environmatal Science \& Technology, 35, 1567-1573.

Århus County, 2000. Århus Bugt 1998. Århus County. In Danish with an English abstract.

Yallop, M.L., Winder, de Ben, Paterson, D.M. \& Stal, L., 1994. Comparative structure, primary production and biogenic stabilization of cohesive and non-cohesive marine sediments inhabited by microphytobenthos. Estuarine, Coastal, and Shelf Science, 39, 565-582.

Young, R.N. \& Southard, J.B., 1978. Erosion of fine-grained marine sediments: Sea-floor and laboratory experiments. Geological Society of America Bulletin, 89, 663-672. 